\title{
Non-profit organisations (NPOs) for sustainable development at community, regional and civil society level
}

\author{
H. Hallemaa \& Ü. Mander \\ Department of Geography, University of Tartu, Estonia
}

\begin{abstract}
Civil society and civil society development is one of the most essential and fundamental questions of the functioning and development of societies. The history and traditions of Estonian societies and associations are long, reaching back to the middle of the $19^{\text {th }}$ century. The topic of the development of civil society reached the public in the second half of the 1990s. The role of non-profit organisations (NPOs) in society is a key question, and they act in the interests of sustainable development at several levels. The civil society and community of NPOs in Estonia is strong and impressive in the EU context. On 1 January 2008 there were 26,363 registered NPOs, and the index of NPOs per 1000 inhabitants was 19.3. This number has continuously grown in the period 2001-2008. On the other hand, there are extremely great differences in the level of development of civil society and NPOs at community or local, regional and civil society level.
\end{abstract}

Keywords: civil society development, civil society organisations (CSO), community development, local development, networks, nongovernmental organisations (NGO), philanthropy, regional development, social capital.

\section{Introduction}

\subsection{Aims and objectives of study}

This article characterizes the development of civil society, the non-profit sector, NPOs, NGOs and CSOs, but first and foremost the role, possibilities and scope of NPOs and NGOs in sustainable development at the civil society, regional and community or local levels in Estonia. The paper presents the results of the joint research carried out from 2000-2008 in two stages: 2000-2005 and 2005-2008. 
The aims and objectives of this study are to analyse the development of Estonian civil society, its characteristics and the regional peculiarities of this development. These results have been published in the Quarterly Bulletin of Statistics Estonia $[1,2]$.

\subsection{The Republic of Estonia and the units of its administrative system}

As we have stated in previous articles [3], the territorial objects that are related to regional and local development and development policy - development units - in Estonia are all units of the Estonian administrative system. These have been characterized in our previous articles $[1,2,4]$. On $1^{\text {st }}$ January 2008 there were 15 counties and 227 local government units, 33 cities and 194 rural municipalities $[1,2]$. The administrative division of Estonia has been presented as of $1^{\text {st }}$ January 2008. The changes in the period under observation have been taken into account in our calculations.

\subsection{Theoretical approaches and grounds for analyses and studies of the development of civil society and NPOs, NGOs and CSOs}

For analyses and the theoretical approaches used in this paper, the conceptions and bases of development of civil society and NPOs, NGOs or CSOs have been used, as well as studies and works by Bourdieu [5], Putnam [6], Salomon et al. [7], Til [8] and others. As described by Bourdieu [5] and Putnam [6], there are three types of capital that are important and needed by all parts of society cultural, social and economical capital. The third sector and civil society itself and NPOs or NGOs acting in society also need these capitals for their operation and work $[5,6]$. At the same time, they are the main producers of social capital. As characterized by Putnam [6], Till [8], Paton [9] and others, there is a widely used concept of social economy and social enterprises, and they are a reality in societies. From the point of view of the individual in society, the activities of NPOs and NGOs affect everyday life in a number of ways [10]. Voluntary actions has been described by Payton as "private action for the public good" [11] and by O'Neill as "private organisation serving a public purpose" [12]. Sumariwalla classifies NPOs as private-sector "non-business" entities, operating either in the public interest or as part of a "whole different" sub-category [13].

\subsection{Scope and content of civil society: understandings, concepts and theoretical approaches}

As established above, there are some understandings and concepts, of the nature, content and extent of civil society [14-17]. In his monograph "Growing Civil Society: From Nonprofit Sector to Third Space", Professor Jon Van Til [10] has mapped the boundaries between various sectors in society and described the development of the public mind, thinking and ideas from the third sector to the third space - civil society. Concepts of and theoretical approaches to sectors of society and civil society have been developed by Til [8, 10], Smith [18, 19], Paton [9], Schuppert [20], Billis [21], Sumariwalla [13], Hall [22], Salomon and 
Anheier [23], Lohmann [24] and others. We have examined and taken into considerations these models, schemes and concepts.

In our understanding and in our simplified model, there are or can be seen to be a minimum of four models or schemes of civil society [14-17] (Fig. 1).

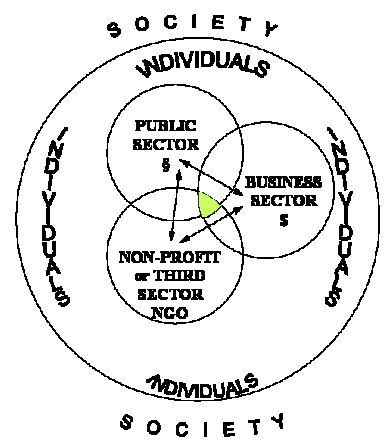

M 1 - civil society in its strictest meaning

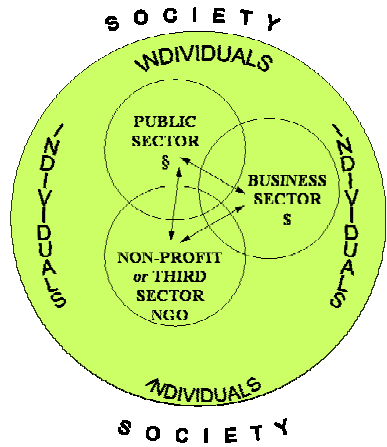

M 3 - civil society in its more extensive meaning: civil society as all society

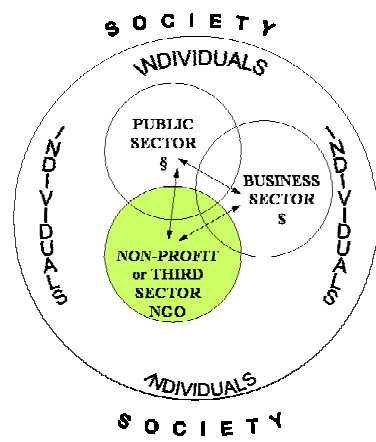

M 2 - civil society as the third sector

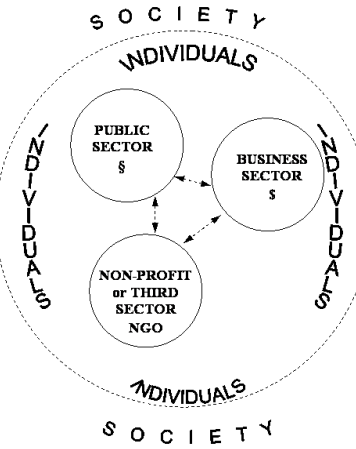

M 4 - societies without civil society

Figure 1: $\quad$ Models or schemes (M) of different understandings of civil society.

In this study and our analyses and survey, we took the third model or scheme as the basis for civil society and the civil society level (Fig. 1).

\subsection{Estonian Civil Society Development Concept (EKAK) and the description of civil society}

At the end of the 1990s, Estonian NGOs, NPOs and CSOs prepared the Approval of the Estonian Civil Society Development Concept (EKAK) [25]. The EKAK was adopted by the $1^{\text {st }}$ General Assembly of the Estonian NGO Roundtable (February 2001) and sent to the Parliament of Estonia, the Riigikogu (May 2001), where it was adopted as a state document and long-term instruction on $12^{\text {th }}$ December 2002 [26]. In processing the EKAK in parliament in close cooperation with NGOs and authorities, some compromises were made: 
Estonia's civil society has been described as the whole society in Approval [25], but as the third sector in the adopted EKAK [26].

\section{Materials and methods}

\subsection{Analyses, survey and description of Estonian civil society}

On 1 January 2008, there were 26,363 registered NPOs in Estonia, of which 24,894 were non-profit associations, 705 were religious organisations and 764 were foundations. It must, however, be taken into account that statistics do not reflect the great number of non-registered or informal societies, especially in rural areas. During this study period (2000-2008), the number of NPOs increased very rapidly, from 12,423 in 2000 to 26,363 in 2008 - during the eight years, the number of NPOs more than doubled $(2.1$ times) $[1,2]$. The number of NPOs per 1000 inhabitants increased steadily in the period 2001-2008, while at the same time the difference between the minimum and maximum indicators in local government units has increased continuously $[1,2]$. The structure and resources of NGOs in Estonia have also been presented by Lagerspetz et al. [27] and other authors.

We have performed analyses of civil society and NGOs and NPOs on the community level in cities and rural municipalities, on the regional level in counties and regions of Estonia and on the civil society level in Estonia as a whole. The following research units have been distinguished: (1) cities, (2) the agglomeration of Tallinn (TLN + the rest of Harju County), (3) rural municipalities, (4) counties, (5) EU NUTS 3 regions [28]: Northern (N), NorthEastern (NE), Central (C); Western (W), and Southern (S) Estonia, (6) development regions and (7) the overall civil society of Estonia.

\subsection{Data and materials for research}

For this study, the basic source data used on the number and structure of NPOs or NGOs or CSOs were received from the Centre of Registers and Information Systems of the Ministry of Justice and from official state registers therein. We use data from the Ministry of Finance on personal income tax received into local government budgets. Population data were obtained from the State Population Register. Some basic data for research and overall calculations was acquired from yearbooks [28] and other official publications of Statistics Estonia [28-34]. We also used the results of previous studies on this topic by the Department of Geography of the Institute of Ecology and Earth Sciences of the University of Tartu $[1-3,14-17,35-37]$. These results have also been presented at international conferences of the International Society for Third-Sector Research (ISTR) [38] and published as abstracts in conference abstracts [14-17].

Based on the data available in the state registers from the Centre of Registers and Information Systems, non-profit organisations or citizens' organisations $(N P O)$ were defined as follows:

$$
N P O=\text { non-profit associations }+ \text { religious associations }+ \text { foundations }
$$


where NPO - non-profit organisations, religious associations - churches, congregations, associations of congregations and monasteries.

\subsection{System for measurement of development of civil society and corresponding indexes used for that purpose}

In order to characterise the role, possibilities and scope of NPOs in the development of community or local, regional and civil society, we have examined and performed statistical analysis using indexes. For this purpose we have taken relatively integrated and informative but also simple indexes describing the potential of development, the level and possibilities of regions on one hand and the strength and development of NPOs and civil society on the other hand $[14,15,35]$ :

(1) The index of personal income tax received into the local budget per capita or per inhabitant is defined as follows:

$$
\text { PIT/inh }=\text { PIT } / \text { No inh, }
$$

where PIT/inh - index of personal income tax received into local budget per capita or per inhabitant; PIT - total sum of personal income tax received into local budget; No inh - total number of inhabitants living on territory of development unit.

(2) The index of non-profit organisations or civil society organisations per 1000 inhabitants is defined as follows:

$$
N P O / R=N P O / R,
$$

where $N P O / R$ - index of non-profit organisations or civil society organisations per 1000 inhabitants; NPO - total number of non-profit organisations; $R$ - total number of inhabitants living on territory of development unit divided by 1000 .

The period for the analysis is the years 2001-2008. In more thorough analyses using personal income tax and related measures, the years 2001, 2004 and 2007 have been used. In the case of the number of NPOs and their measures, the years 2002, 2005 and 2008 (as of 1 January) have been used.

\subsection{Groups by the level of civil society development and development resources for integrated analyses of civil society}

We have created five groups of development units based on the level of development of civil society or NPOs and the potential used development resources [15, 35], based on indexes NPO/R and PIT/inh (Table 1). The distribution was made on the basis of the Estonian average value of both indexes. The area where the values of both indexes are below the Estonian average has been divided in two. The division line goes along the line where the receipt of income tax in the local government budget equals $75 \%$ of the Estonian average. 
Table 1: Groups defined on the basis of the level of development of civil society (NPO/R) and development resources (PIT/inh) [15, 35].

\begin{tabular}{|l|l|l|}
\hline Group & NPO/R & PIT/inh \\
\hline I & Above the Estonian average & Above the Estonian average \\
\hline II & Above the Estonian average & Below the Estonian average \\
\hline III & Below the Estonian average & Above the Estonian average \\
\hline IV & Below the Estonian average & $\begin{array}{l}\text { Below the Estonian average: the upper half } \\
(75 \%-99 \% \text { of the Estonian average) }\end{array}$ \\
\hline V & Below the Estonian average & $\begin{array}{l}\text { Below the Estonian average: the lower half } \\
\text { (less than } 75 \% \text { of the Estonian average) }\end{array}$ \\
\hline
\end{tabular}

\subsection{Statistical analyses of the relationship between indexes of the level of civil society development and development resources}

For statistical analyses and data processing we use the program STATISTICA 6.0. The normality of variables was checked using the Lilliefors' and Shapiro-Wilk's tests. For all variables the distributions were asymmetrical and skewed towards smaller values, and hence nonparametric methods were used.

We have calculated Spearman Rank Order Correlations or Spearman Rank Order Correlation coefficients by counties and local administrations and inside regions of Estonia between NPO/R and PIT/inh.

The indexes of NPO/R and PIT/inh were normally distributed, and thus we also partly used a parametric method - linear regression analysis. We found a linear relationship between the variables and the coefficient of determination $\mathrm{R}^{2}$, which describes the percentage (\%) of the total variability of the model.

Harju County, including the city of Tallinn, the capital of Estonia, its conurbation, its nearest hinterlands and most of the distant hinterland [39], differed from other areas. For this reason, in linear regression analysis we also performed comparative calculations without including Harju County. The results of the statistical analyses presented in this paper are based on the first stage of the joint research.

\subsection{Classification and groups of NGOs and NPOs by field of activity}

NPOs operate in different fields of activity. In order to analyse the landscape of civil society and the structure of fields of activities of NPOs and foundations, we have developed a classification of NPOs or NGOs by fields of activity, which contain a division into nineteen groups $[1,2]$ : I Agriculture, hunting, forestry and fishing; II Apartment associations, garage associations and other real estate management; III Research and development; IV Education, incl. Training; V Health; VI Social care; VII Sports clubs and sporting activities; VIII Activities of commercial, employers' and professional organisations; IX Activities of trade unions; X Activities of religious organisations; XI Protection and custody of civil rights; XII Associations and funds promoting regional/ local community life; XIII Youth and children's associations and associations promoting the welfare of children and young people; XIV Associations of national minorities and cultural societies; XV Associations engaged in leisure time, recreational and cultural or 
hobby activities, and hobby clubs; XVI Environmental and nature protection associations; XVII Associations of handicapped people; XVIII Activities of other organisations not included in groups VIII-XVII and XIX Other.

The distribution is based on the main economic activity of NPOs as defined by the Estonian Classification of Economic Activities EMTAK 2008 [40], which is an Estonian national version by Statistics Estonia of the Statistical Classification of Economic Activities in the European Community NACE Rev. 2 by Eurostat [41].

\section{Results and discussion}

\subsection{Comparing regional differences of level of development of civil society and between NPOs and its dynamics at the civil society level in Estonia as a whole}

There are great differences between the number and structure of NPOs in various Estonian regions. These differences are directly influenced by the resources available for the development of civil society. In 2001 the number of NPOs per 1000 inhabitants was below the Estonian average in 163 local government units, which accounted for $71.8 \%$ of the total number of local government units. In 2002 the respective figures were 173 and $76.2 \%$. Thereafter the situation improved somewhat, but at the beginning of 2008 the number of NPOs per 1000 inhabitants was 19.3 on average, and the respective indicator was above this in only 54 local government units $(23.8 \%)$. In thirteen county centres the number of NPOs exceeds the Estonian average. The resource is significantly greater than the average for Estonia in local government units around Tallinn [1, 2].

\subsection{Regional differences in the level of development of civil society and between NPOs at the regional level in EU NUTS 3 regions and counties of Estonia}

The results of the study and regional differences in NPO/R in EU NUTS 3 regions and counties of Estonia and its dynamics in the years 2001 and 2008 are shown in Fig. 2.

On the counties level, the respective indicator (NPO/R) is higher in Western Estonia. Civil society is more developed along the Tallinn-Pärnu axis. In comparing the years 2001 and 2008, one can notice significant development in all counties $[1,2]$. Of EU NUTS 3 regions, this index and the number of NPOs is and has been the highest in Northern Estonia in all years of the period 2001-2008 (2001-11.0, 2008-21.8). Western Estonia has also surpassed the Estonian average. In North-Eastern Estonia, civil society is least developed and has the lowest figures for the NPO/R index over all of the years we examined (2001-7.0, 2008-15.7). Central and Southern Estonia is also below the Estonian average.

\subsection{Regional differences in level of development of civil society and between NPOs at municipal and community level in Estonia}

The results of the study and the extremely great differences in the level of development of civil society and NPOs at the municipal level in Estonia are 


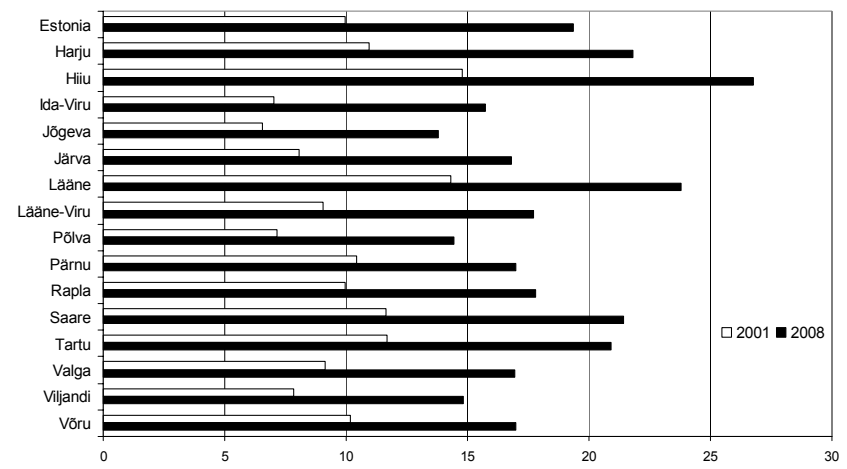

Figure 2: Non-profit organisations per 1000 inhabitants by county and in EU NUTS 3 regions of Estonia, 2001 and 2008 (at beginning of year).

presented in Fig. 3 (2001) and Fig. 4 (2008).

In thirteen county centres the number of NPOs exceeds the Estonian average. In 175 local government units, the NPO/R index was below the Estonian average. Big cities and their hinterlands can be distinguished as the most developed regions. The resource is also significantly bigger than the Estonian average in local government units in the vicinity of Tallinn $[1,2]$.

\subsection{EU NUTS 3 regions, counties and local government units by groups of the level of development of civil society and development resources and dynamics}

Fig. 5 presents the results of research into the distribution of counties and EU NUTS 3 regions by groups of the level of development of civil society and development resources. We have also compared regions by the relevant dynamics during the period 2001-2007 [1,2].

Regarding counties, only Harju County was in relatively good group I during the period 2001-2007. Calculations show that two-thirds of the counties are in groups IV and $\mathrm{V}$, thus falling below the Estonian average with respect to the number of NPOs and personal income tax received, or in these counties civil society is at a low level of development and there are limited resources for development.

The distribution of population between groups provides quite a positive picture: over $56 \%$ of the Estonian population belongs to groups I and II, which are the most essential from the point of view of the development of civil society. The population in group I shows a slow growth trend - this is also a positive sign $[1,2]$. Of EU NUTS 3 regions, there is a positive situation in Northern Estonia and Western Estonia, which have been in group I and group II respectively in all of the years from 2001 to 2007. In contrast, North-Eastern Estonia has been in the worst group, V, throughout this period. Central Estonia is in group IV, and Southern Estonia has also been in this group since 2002 also. 


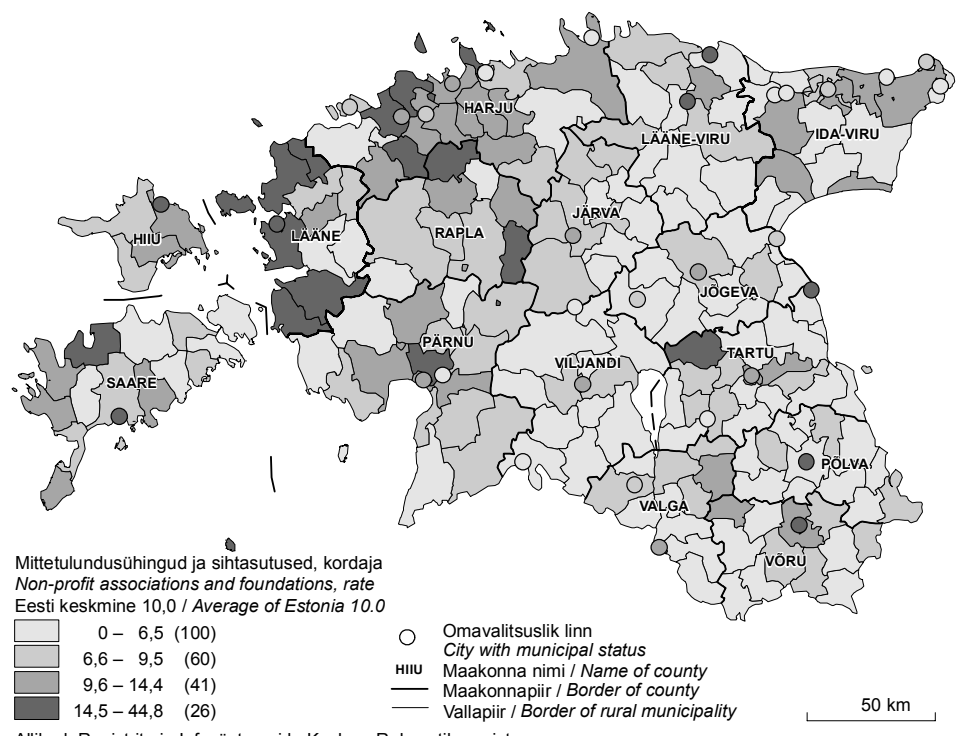

Allikad: Registrite ja Infosüsteemide Keskus, Rahvastikuregister.

Sources: Centre of Registers and Information Systems, Population Register.

Figure 3: Non-profit organisations per 1000 inhabitants in Estonian local government units, January 2001.

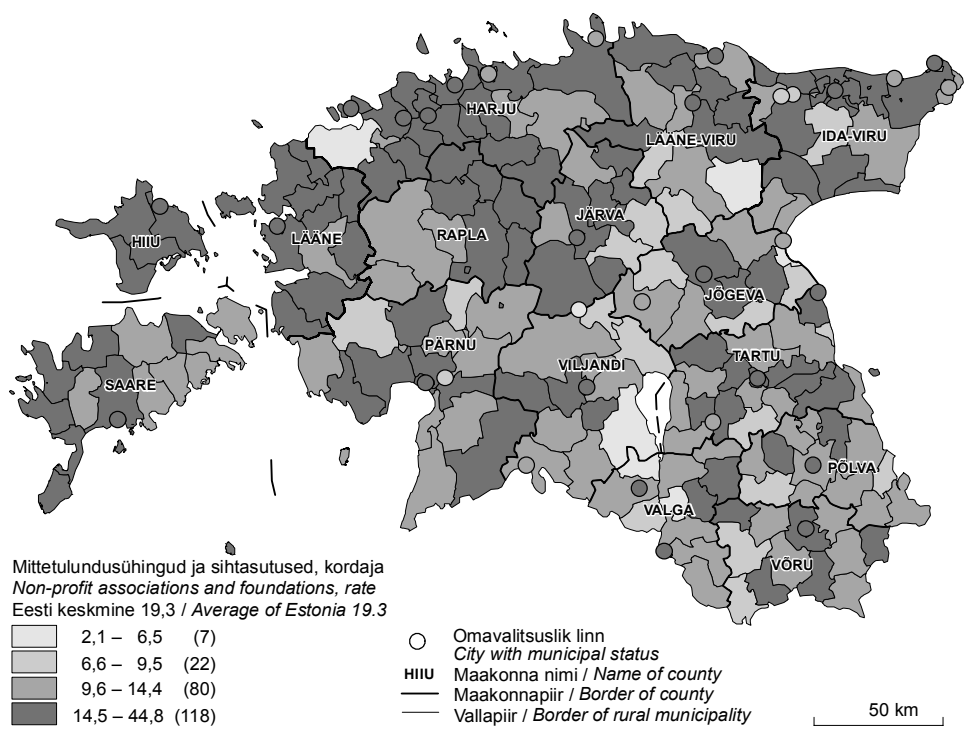

Allikad: Registrite ja Infosüsteemide Keskus, Rahvastikuregister.

Sources: Centre of Registers and Information Systems, Population Register.

Figure 4: Non-profit organisations per 1000 inhabitants in Estonian local government units, January 2008. 


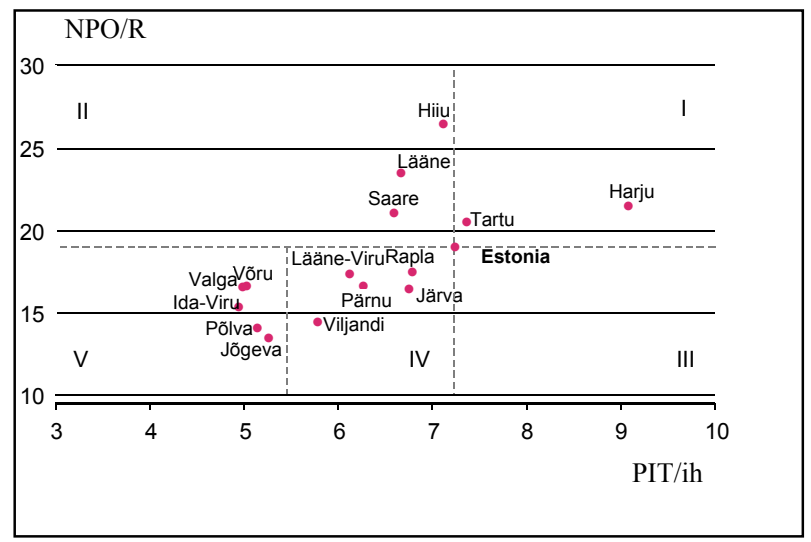

Figure 5: Distribution of counties and NUTS 3 regions of Estonia by the level of development of civil society and development resources, 2007. For an explanation of groups indicated by Roman numerals, see Table 1.

\subsection{Relationship between resources and potential and development level of civil society and indexes in Estonian regions: results of statistical analyses}

Based on the results of our previous statistical analyses and data processing [15, 35, 36], Spearman Rank Order Correlations of the counties of Estonia were significant between indexes, and varied from 0.654 to 0.846 . The discovered linear relationship between the variables is described in previous articles. When Harju County is excluded, the linear relationship between the variables becomes stronger: the coefficient of determination, $\mathrm{R}^{2}$, is higher. The relationship between indexes exists and is quite strong.

\subsection{Distribution of NPO-s by field of activity and respective regional characteristics}

The results of our study - the distribution of NPOs in Estonia in 2002, 2005 and 2008 by field of activity - are presented in Fig. 6.

The NPOs registered in Estonia mostly consist of apartment associations, garage associations and associations engaged in other real estate management activities (accounting for 11,812 or $44.8 \%$ in 2008). In terms of absolute figures, NPOs embrace a considerable number of sports clubs and associations engaged in sports activities (3057 or 11.6\% in 2008), NPOs engaged in leisure time, recreational, cultural and hobby activities, and hobby clubs (2072 or $7.9 \%$ ), NPOs of commercial, employers' and professional organisations (1667 or $6.3 \%$ ), NPOs promoting and supporting regional/local community life (1001 or 3.8\%), followed by all other associations, which were fewer in number. The number of NPOs grew most rapidly in the groups that are important from the perspective of local and regional development: NPOs promoting regional/ local community life 


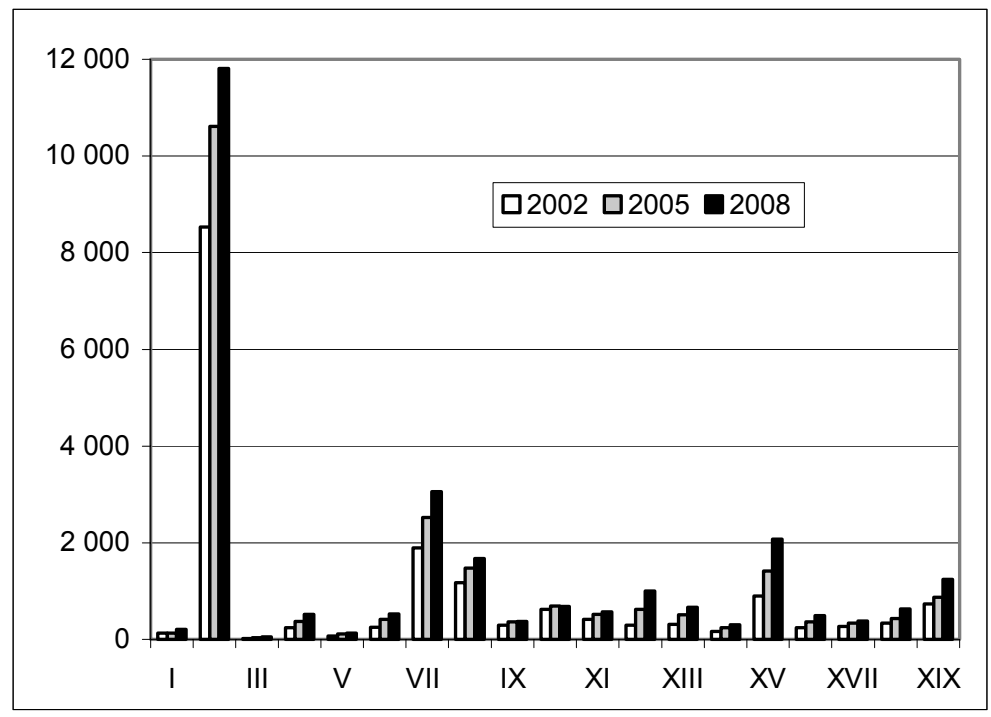

Figure 6: Distribution of NPOs in Estonia by field of activity, $1^{\text {st }}$ January 2002, 2005 and 2008. For explanation of Roman numerals, see section 2.6.

(342.8\% by 2008 compared to 2002); in the group of research and development $(282.4 \%)$, but also in case of associations engaged in education, incl. training $[1,2]$.

\subsection{Perspectives and development of civil society and NGOs and NPOs in Estonia}

The Estonian Civil Society Development Concept (EKAK) was adopted by the Parliament of Estonia in December 2002 [26]. On the basis of this concept, several strategic documents have been created: a development plan for civic initiative support for the years 2007-2010 [42], a development plan for volunteer efforts for 2007-2010 [43] etc. The next steps should be to establish EKAKs etc. on the regional and local levels.

Our research and long-term survey also demonstrated that there are enormous differences between regions of Estonia in terms of the structure, number and development characteristics of NPOs and NGOs and the level of development of civil society. We can observe the same tendencies in the regional and community-level development of Estonia [29]. All European and other countries use regional policy in several ways [44]. In Estonia today, it is essentially necessary to increase the size and capacity of the stimulation of regional policy, based on support for enterprises and also NPOs [45].

We have described and pointed out several participants, social partners and actors, different kinds of groups and the main sources of direct funding of and for community development [14-17]. We have taken the Baltic Sea NGO 
Network [15, 17, 46] and the Central and Eastern European Citizens' Network as good examples of the participation of NGOs in civil society, regional and community development and the implementation of these principles on the international level and by international regions [17].

\section{Conclusions}

In Estonia, joint action and the development of civil society have been brought into focus once again. Estonia has a relatively well-developed, strong and impressive civil society and community of NPOs. There are more than 27,000 registered NPOs, and the index of NPOs per 1000 inhabitants is over 19. There exists quite a rather strong relation or correlation between the two indexes: NPOs per 1000 inhabitants, NPO/R and personal income tax received into the local budget per capita or inhabitant PIT/inh. The number of NPOs grew most rapidly in the groups whose fields of activity are important for local and regional development. At the same time, there are also extremely great differences between regions of Estonia in terms of the structure, number and characteristics of the development of NPOs and NGOs and the level of development of the civil society. These differences are increasing rather than decreasing, and will at best remain at the same level. In Estonia today it is crucial that the size and capacity of the stimulation of regional policy be increased, based on support for enterprises and also NPOs [45].

\section{Acknowledgements}

This study was supported by the Ministry of Education and Science of Estonia (grants SF0182534s03 and SF0180127s08) and Estonian Science Foundation grants 6083 and 7527.

\section{References}

[1] Hallemaa, H. \& Servinski, M., Non-profit organisations and development of civil society. Quarterly Bulletin of Statistics Estonia, 01/09, Statistics Estonia: Tallinn, pp. 58-89, 2009. [www] http://www.stat.ee/31375 (31.05.2009) (In Estonian, tables and figures in Estonian and English)

[2] Hallemaa, H. \& Servinski, M., Non-profit organisations and development of civil society. Quarterly Bulletin of Statistics Estonia, 01/09, Statistics Estonia: Tallinn, pp. 90-99, 2009. [www] http://www.stat.ee/31376 (31.05.2009)

[3] Hallemaa H., Regional Development and Development Policy in Estonia and European Community. Economical Policy of Estonia in European Union, Tallinn Technical University: Tallinn \& University of Tartu: Tartu, pp. 42-62, 1996. (In Estonian, summary in English)

[4] Hallemaa, H., Vitsur, H., Oja, T. \& Mander, Ü, The sustainability of energy use in Estonian settlements and regions. Mander, $\ddot{U}$., Brebbia, $C$. A. and Tiezzi, E. (eds.) The Sustainable City IV. Urban Regeneration and Sustainability, WIT Press: Southampton \& Boston, pp. 509-520, 2006. 
[5] Bourdieu, P., Acts of Resistance: Against the New Myths of Our Time. Polity Press: Oxford, 1998.

[6] Putnam, R. D., The Prosperous Community: Social Capital and Public Life. The American Prospect, Vol. no. 13, spring, pp. 35-42, 1993.

[7] Salomon, L. M., Anheier, H. K. et al, The Emerging Sector Revisited: A Summary. Revised Estimates, Center for Civil Society Studies, Institute for Policy Studies and The Johns Hopkins University Oress: Baltimore, USA, 1998.

[8] Til, J. V., Mapping the Third Sector: Voluntarism in a Changing Social Economy, The Foundation Center: New York, 1988.

[9] Paton, R., The Social Economy: Value-Based Organizations in the Wider Society. Til, J. V., Batsleer et al (eds.), Issues in Voluntary and Non-profit Management, Chapter 1, Addison-Wesley: Wokingham (U.K.), 1991.

[10] Til, J. V., Growing Civil Society: From Nonprofit Sector to Third Space, Indiana University Press: Bloomington \& Indianapolis, 241 pp., 1998.

[11] Payton, R., Major Challenges in Philanthropy. Proceedings of the 1984 Independent Sector Meeting and Spring Forum, Hodkinson, V. (ed.), Independent Sector: New York, 1984.

[12] O'Neill, M., The Third America: The Emergence of the Nonprofit Sector in the United States, Jossey-Bass: San Francisco, 1989.

[13] Sumariwalla, R., Preliminary Observations in Scope, Size and Classification of the Sector. Hodgkinson, V. (ed.), Working Papers for the Spring Research Forum: Since the Filer Commission, Independent Sector: Washington, D.C., pp. 433-449, 1983.

[14] Hallemaa, H., Development of non-profit sector and civil society and NGO support systems in Estonia. ISTR Fifth International Conference: Conference Abstracts [38], 2002. [www] http://www.istr.org/conferences /capetown/abstracts/hallemaa.html (31.05.2009)

[15] Hallemaa, H., Nonprofit Organizations in Regional and Civil Society Development: Estonian case and results of studies. ISTR Sixth International Conference: Conference Abstracts [38], 2004. [www] http://www.istr.org/conferences/toronto/abstracts/Hallemaa.pdf (31.05.2009)

[16] Hallemaa, H., Role and Contribution of NPO-s to Regional and Civil Society Development: Baltic Sea Region case. ISTR Seventh International Conference: Conference Abstracts [38], 2006. [www] http://www.istr.org /conferences/bangkok/abstracts/abstract/Hallemaa.pdf (31.05.2009)

[17] Hallemaa, H., NPOs In and For Community, Regional and Civil Society Development: Several Cases. 8th International Conference of ISTR and 2nd European Conference of the EMES and ISTR: Conference Abstracts [38], 2008. [www] http://www.istr.org/conferences/barcelona/cd/pdf /abstracts/Helmut\%20Hallemaa.pdf (31.05.2009)

[18] Smith, D. H., Four Sectors or Five? Retaining the Member-benefit Sector. Nonprofit and Voluntary Sector Quarterly 20, no. 2, pp. 137-150, 1991.

[19] Smith, D. H., The Rest of the Nonprofit Sector: Grassroots Associations and the Dark Matter Ignored in Prevailing. 'Flat Earth' Maps of the 
Sector. Nonprofit and Voluntary Sector Quarterly 26, no. 2 (June), pp. 114-131, 1997.

[20] Schuppert, G. F., State market, Third Sector: problems of Organizational Choice in the Delivery of Public Services. Nonprofit and Voluntary Sector Quarterly 20, pp. 123-136, 1991.

[21] Billis, D., Organising Public and Voluntary Agencies, Routledge: London, 1993.

[22] Hall, P. D., Inventing the Nonprofit Sector and Other Essays on Philanthropy. Voluntarism and Nonprofit Organizations, Johns Hopkins University Press: Baltimore, 1992.

[23] Salomon, L. and Anheier H. K., In Search of the Nonprofit Sector, I: The Question of Definition. Voluntas, The International Journal of Voluntary and Non-Profit Organizations, (March), 1992.

[24] Lohman, R., The Commons: New perspectives on Nonprofit Organizations and Voluntary Action, Jossey-Bass: San Francisco, 1992.

[25] Estonian Civil Society Development Concept: Approval, Prepared by D. Liiv in close co-operation with the project expert group, Estonian NGO Roundtable: Tallinn, 11 pp., 2001.

[26] Estonian Civil Society Development Concept, Adopted by decision of Estonian Parliament Riigikogu on the 12 of December 2002. State Informer chapter I, 103, 606, State Chancellery of Estonian Government: Tallinn, 5 pp., 2002. [www] http://www.siseministeerium.ee/public /Estonian_Civil_society_Development_Concept.doc (31.05.2009)

[27] Lagerspetz, M. Rikmann, E. \& Ruutsoo, R., The Structure and Resources of NGOs in Estonia. Voluntas: International Journal of Voluntary and Nonprofit Organizations, Vol. 13, No. 1, International Society for ThirdSector Research, The Johns Hopkins University and Springer: Johannesburg: pp. 73-87, 2002. [www] www.springerlink.com (31.05.09)

[28] Estonian Statistical Yearbooks 1991-2008, Statistics Estonia: Tallinn, 1992-2009.

[29] Regional development of Estonia 1995-2000, Statistics Estonia \& Estonian Ministry of Interior: Tallinn, 2002.

[30] Counties in Figures 1996-2000, Statistics Estonia: Tallinn, 2001.

[31] Counties in Figures 1998-2002, Statistics Estonia: Tallinn, 2003.

[32] Counties in Figures 2000-2004, Statistics Estonia: Tallinn, 2005.

[33] Counties in Figures 2002-2006, Statistics Estonia: Tallinn, 2007.

[34] Cities and Rural Municipalities in figures 2001-2008, Statistics Estonia: Tallinn, 2001-2008.

[35] Hallemaa, H., Non-profit organizations in civil society development and regional picture of civil society. Cities and rural municipalities in figures 2004, Statistics Estonia: Tallinn, pp. 59-76, 2004. (In Estonian, summary, tables and figures in English)

[36] Hallemaa, H., Nonprofit Organizations in Regional and Civil Society Development: Estonian case and results of studies. In: IV Baltic Sea NGO Forum 16-17 April 2004 Starnd Spa and Conference Hotel Pärnu, 
Estonia., Estonian NGO Roundtable and Baltic Sea NGO Forum: Tallinn - Pärnu, pp. 95-98, 2004.

[37] Servinski, M., Lehto, K. \& Hallemaa, H., Regional development of social cohesion. Social trends 4, Statistics Estonia: Tallinn, pp. 125-139, 2007.

[38] ISTR International Conferences (5, 6, 7, 8) Cape Town 2002, Toronto 2004, Bangkok, 2006, Barcelona 2008: Conference Abstracts, ISTR, 2002, 2004, 2006, 2008. [www] http://www.istr.org/conferences (31.05.2009)

[39] Potentials and prerequisites Estonia Tallinn Region. Baltic Palette II.AG 1a.Palette Polycentric Platform Project - PPPP, Harju County Government: Tallinn, 2004. [www] http://www.balticpalette.com/dl /BPIIAG1Estonia.pdf (9.01.2009).

[40] Estonian Classification of Economic Activities EMTAK 2008, Statistics Estonia: Tallinn, 58 pp., 2007. [www] http://www.rik.ee/32971 (31.05.2009) (In Estonian)

[41] Statistical classification of economic activities in the European Community NACE Rev. 2: Structure and explanatory notes, Eurostat Unit 02 Statistical governance, quality and evaluation: Brussels, 194 pp., 2007. [www] http://www.rik.ee/32971 (31.05.2009)

[42] Development plan for civic initiative support 2007-2010, adopted by ordinance No. 350 of Government of Estonia from 15 June 2006. State Informer, annex, 49, 915, State Chancellery of Estonian Government: Tallinn, 11 pp., 2006. [www] http://www.siseministeerium.ee/public /KATA_310506_eng.doc (31.05.09)

[43] Development plan for volunteer efforts 2007-2010, Tartu Volunteers Centre \& Estonian Ministry of Interior: Tallinn-Tartu, 10 pp., 2006. [www] http://www.vabatahtlikud.ee/UserFiles/arengukava/vta_2007_ 2010_31_jaan_2007.pdf (31.05.2009) (In Estonian)

[44] The International Evaluation Conference of Finnish regional policy. Briefing material: Moviste 14/1991, Helsinki, 1991.Roundtable and Baltic Sea NGO Forum: Tallinn - Pärnu, pp. 20-24, 2004.

[45] Regional Development Strategy of Estonia 2005-2015, Regional Development Department of Estonian Ministry of Interior: Tallinn, 27 pp., 2007.[www]http://www.siseministeerium.ee/public/Eesti_regionaalarengu strateegia_2005_2015_eng_tolge.doc (31.05.2009)

[46] $\bar{B}$ Baltic Sea NGO Forum 16-17 April 2004 Strand Spa and Conference Hotel Pärnu, Estonia: (Materials), Estonian NGO Roundtable and Baltic Sea NGO Forum: Tallinn - Pärnu, 99 pp., 2004. 